\title{
ИЗУЧЕНИЕ АНКСИОЛИТИЧЕСКОЙ АКТИВНОСТИ ПРОИЗВОДНОГО ДИАЗЕПИНО[1,2-А]-БЕНЗИМИДАЗОЛА ПОД ЛАБОРАТОРНЫМ ШИФРОМ ДАБ-21
}

\author{
М.В. Мирошников ${ }^{1,2}$, Д.В. Мальцев ${ }^{1,2}$ \\ ${ }^{1}$ Кафедра фармакологии и биоинформатики, Федеральное государственное бюджетное \\ образовательное учреждение высшего образования «Волгоградский государственный \\ медицинский университет» Минздрава России, \\ 400131, Россия, г. Волгоград, площадь Павших Борцов, д. 1. \\ 2Лаборатория экспериментальной фармакологии, Государственное бюджетное \\ учреждение «Волгоградский медицинский научный центр». \\ 400131, Россия, г. Волгоград, площадь Павших Борцов, д. 1.
}

DOI: 10.19163/MedChemRussia2021-2021-473

E-mail: mihailmiroshnikov@mail.ru

Тревожные расстройства - одна из наиболее распространенных поведенческих патологий в мире. Количество неврологических заболеваний, связанных с тревожной симптоматикой, неуклонно растет. Существует большое количество препаратов для лечения данных патологий, но все они обладают в разной степени выраженности побочными эффектами, среди которых: физическая зависимость, абстинентный синдром, седация, снижение концентрации внимания. На основании ранее проведенных экспериментов было проведено углубленное изучение анксиолитической активности производного диазепино-бензимидазола ДАБ-21 (11-[2-(1-пирролидил)этил]-2,3,4,5-тетрагидро[1,3]диазепино[1,2-а]бензимидазол дигидрохлорид) на ряде поведенческих моделей [1,2].

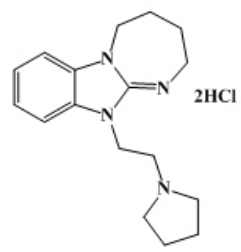

Puc. 1. Структура соединения ДАБ-21

Выявлена способность вещества устранять тревожную симптоматику, анксиолитическая активность изучаемого соединения превышала таковую препарата сравнения диазепама.У вещества ДАБ-21 не было выявлено серьезных побочных эффектов, что в совокупности с полученными данными может свидетельствовать о перспективности данного соединения [2]. Исследование выполнено при финансовой поддержке РФФИ в рамках научного проекта № 20-015-00164/20.

\section{Литература}

[1] Д.В. Мальцев, .А.А. Спасов, М.В. Мирошников и др. Анализ взаимодействия производного диазепино [1, 2-а] бензимидазола соединения ДАБ-21 с основными лигандами нейромедиаторных систем //Вестник Волгоградского государственного медицинского университета. - 2021. - №. 1 (77).

[2] Maltsev, D. V., Spasov, A. A., Yakovlev, D. S. et al. Searching for new anxiolytic agents among derivatives of 11-dialkylaminoethyl-2, 3, 4, 5-tetrahydrodiazepino [1, 2-a] benzimidazole // European Journal of Pharmaceutical Sciences. - 2021. - T.161. - C. 105792. 